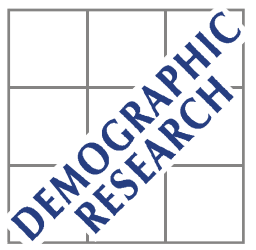

Demographic Research a free, expedited, online journal of peer-reviewed research and commentary in the population sciences published by the Max Planck Institute for Demographic Research Konrad-Zuse Str. 1, D-18057 Rostock · GERMANY www.demographic-research.org

DEMOGRAPHIC RESEARCH

SPECIAL COLLECTION 2, ARTICLE 10

PUBLISHED 16 APRIL 2004, PAGES 255-276

www.demographic-research.org/special/2/10/

DOI: $10.4054 /$ DemRes.2004.S2.10

Research Article

\title{
Cause-specific contributions to black-white differences in male mortality from 1960 to 1995
}

Irma T. Elo

Greg L. Drevenstedt

The papers in this special collection were presented at the seminar "Determinants of Diverging Trends in Mortality", held at MPIDR, Rostock on 19-21 of June, 2002. The seminar was organized by the Max Planck Institute for Demographic Research and the Committee on Emerging Health Threats of the International Union for the Scientific Study of Population.

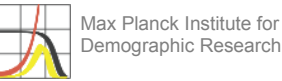




\section{Table of Contents}

$\begin{array}{lll}1 & \text { Introduction } & 256\end{array}$

2 Data and methods 256

2.1 Data 256

2.2 Methods 258

3 Results 259

3.1 Trends in all-cause mortality 259

3.2 Cause-specific contributions to black-white 262 differences in male mortality

$\begin{array}{lll}4 & \text { Discussion } & 269\end{array}$

5 Acknowledgement 271

References 272

$\begin{array}{ll}\text { Appendix } & 276\end{array}$ 


\title{
Cause-specific contributions to black-white differences in male mortality from 1960 to 1995
}

\author{
Irma T. Elo ${ }^{1,2}$ \\ Greg L. Drevenstedt ${ }^{1}$
}

\begin{abstract}
Between 1960 and 1995 the black-white difference in male life expectancy in the United States increased from 6.7 years to 8.2 years. To provide insights into why mortality trends have been more adverse for black men than for white men, we investigate which causes of death were principally responsible for changes in the blackwhite difference in male mortality at ages 15-64 between 1960 and 1995. We find that black-white differences in male mortality varied substantially during this period. The gap increased in the 1960s, declined in the 1970s, and widened in the 1980s-early 1990s. Our findings reveal considerable variation in black-white disparities by cause of death and by age, as well as changes in the relative importance of various causes of death to the black-white male mortality disparity over time. The results suggest that consequences of black-white differences in socioeconomic status, access to quality health care, living conditions, and residential segregation vary by cause of death.
\end{abstract}

Population Studies Center, University of Pennsylvania, 3718 Locust Walk, Philadelphia, PA

19104, USA.

2 Corresponding author. Phone: (215) 898-9162. Email: popelo@ pop.upenn.edu. 


\section{Introduction}

Despite unprecedented mortality declines during the 20th century, substantial differentials in death rates persist by race and socioeconomic status in the United States (Elo and Preston 1996; Geronimus et al. 1996; National Center for Health Statistics (NCHS) 1998; Smelser, Wilson and Mitchell 2001). Black males have fared particularly poorly in terms of health and longevity relative to other population subgroups. In 1995 black male life expectancy at birth (65.2 years) had not yet reached that of white males in 1960 (67.4 years). Furthermore, the black-white difference in male life expectancy increased from 6.7 years in 1960 to 8.2 years in 1995 (NCHS 1998). These disparities are an important public health concern and raise serious questions about the impact of societal inequalities.

Why have mortality trends been so much more adverse for black men than for white men? We examine this question by focusing on cause-specific mortality trends between 1960 and 1995 and by assessing contributions of specific causes of death to changes in the black-white difference in male mortality at ages 15-64. We also examine contributions of specific causes of death to the black-white male mortality difference in 1960-62 and 1993-95. Mortality differences at these ages accounted for 58 percent of the black-white gap in male life expectancy in 1960 and 75 percent in 1995.

Differences in all-cause mortality reflect underlying cause-specific disparities between whites and African Americans. The identification of causes of death that have contributed to these differences and to changes in the black-white disparity over time can shed light on underlying factors. Although there have been previous analyses of racial differences in cause-specific mortality and changes in cause-specific mortality over time (Geronimus et al. 1996; Manton, Patrick and Johnson 1987; Potter 1991; Rogers 1992), we do not know of any study that has attempted to provide a systematic assessment of black-white differences in male mortality in young adulthood and middle age covering the entire 35-year period. We also know of no studies that have decomposed changes in these differentials according to specific causes of death.

\section{Data and methods}

\subsection{Data}

Our analyses focus on white and black men at ages 15-64. We further divide this age range into two groups -- ages 15-39 and 40-64 -- because the relative importance of specific causes of death varies by age. Intentional and unintentional injuries are more 
important at younger ages while chronic diseases dominate at ages 40-64. We also split the 35-year time period into three intervals, which correspond to changes in the blackwhite difference in male mortality: 1960-67, 1968-83, and 1984-95. Black-white differences increased in the first and last periods, while they narrowed in the middle period.

We first calculate annual age-specific death rates for all causes combined and for specific causes of death for white and black males between ages 15 and 64 for 1960-95 using vital statistics data on deaths and the U.S. Census Bureau's population estimates from 1960 through 1995 (Centers for Disease Control 2001; U.S. Census Bureau 1974). Yearly population estimates were adjusted for census undercount because of large racial differences in census omission rates (Preston et al. 1998; Robinson et al. 1993; U.S. Census Bureau 1988). For intercensal years, we interpolated undercount estimates by race and age; 1990 estimates are used for 1990-95. These corrections make larger adjustments to the number of African American males than white males because the former are much more likely to be missed in decennial population censuses. Death rates for the two 25-year age intervals were age-standardized using the 2000 U.S. population as a standard (Anderson and Rosenberg 1998).

The Centers for Disease Control provided mortality data for 1960-67 and data for 1968-95 were extracted from the publicly available Mortality Detail Files (1968-91) and Multiple Cause of Death Files (1992-95) produced by the National Center for Health Statistics (NCHS). Deaths were coded using the Seventh (1960-67), Eighth (1968-78), and Ninth Revisions (1979-95) of the International Classification of Diseases (ICD). Although we investigated 23 specific causes at younger ages and 33 causes at older ages, we focus our presentation on the following causes: infections, pneumonia, and influenza; cancer, with cancer deaths further divided into lung cancer and all other cancers combined at ages 40-64; diabetes; stroke; circulatory diseases (except stroke); cirrhosis of the liver; homicide; suicide; all other intentional and unintentional injuries; and all other causes combined. For the period 1984-95, we also separate deaths due to human immunodeficiency virus (HIV) infection. ICD numbers for each cause group are shown in Appendix Table A1.

Two additional issues concerning the cause of death classification warrant mention. First, during the 1980s, HIV infection emerged as a major public health threat whereby, within a short period of time, HIV/AIDS became one of the leading causes of death for certain age groups and contributed substantially to mortality differences by race (Kochanek, Maurer and Rosenberg 1994). For 1984-86, most HIV-related deaths were assigned to the category of "deficiency of cell-mediated immunity" (ICD No. 279.1) (NCHS 1986). We use ICD No. 279.1 to identify AIDS deaths in 1984-86 and NCHS special codes *042-*044 to identify them from 1987-95 (NCHS 1989). An inspection of age-standardized death rates by cause in 1983-86 suggest that some of the 
AIDS deaths may have been included under the category "other infectious and parasitic diseases" prior to 1987 (which includes all infectious and parasitic diseases). Thus, we have more confidence in the reporting of HIV-related deaths beginning in 1987.

Second, our classification of causes of death is based on the underlying cause concept, defined by the World Health Organization as "(a) the disease or injury which initiated the train of morbid events leading directly to death, or (b) the circumstances of the accident or violence which produced the fatal injury." It represents the cause of death reported on the death certificate that is thought to be the most relevant for public health (Rosenberg 1999). We do not make use of multiple cause of death data in these analyses and therefore may underestimate the overall contribution of various causes of death to racial difference in male mortality (Israel, Rosenberg and Curtin 1986; Manton, Patrick and Johnson 1987). Information on underlying cause of death is less problematic for younger individuals than for the elderly. Limiting our analyses to ages 15-64 minimizes these problems.

\subsection{Methods}

We computed two cause-specific measures that decompose the black-white mortality difference by cause of death. We focus on the absolute difference in death rates rather than the ratio of the rates because absolute differences translate directly into differences in life expectancy. This approach permits us to examine the contributions of various causes of death to the black-white mortality difference at a point in time and trends in these differences over time, as well as avoiding the instability in ratios of death rates based on small numbers of deaths.

The proportionate contribution of each cause to the overall difference in male mortality at the beginning (1960-62) and end (1993-95) of the study period for each age group is obtained by dividing the black-white difference in each cause-specific rate by the black-white difference in the all-cause death rate:

$$
\mathrm{p}_{\mathrm{i}}=\left({ }_{25} \mathrm{ASDR}_{\mathrm{x}, \mathrm{i}}^{\mathrm{B}}-{ }_{25} \mathrm{ASDR}_{\mathrm{x}, \mathrm{i}}^{\mathrm{W}}\right) /\left({ }_{25} \mathrm{ASDR}_{\mathrm{x}}^{\mathrm{B}}-{ }_{25} \mathrm{ASDR}^{\mathrm{W}}{ }_{\mathrm{x}}\right),
$$

where ${ }_{25} \mathrm{ASDR}_{\mathrm{x}, \mathrm{i}}^{\mathrm{B}}$ and ${ }_{25} \mathrm{ASDR}_{\mathrm{x}}^{\mathrm{B}}$ represent age-standardized black male death rates for cause $\mathrm{i}$ and for all causes combined at ages $\mathrm{x}$ to $\mathrm{x}+25$ respectively, and ${ }_{25} \mathrm{ASDR}_{\mathrm{x}, \mathrm{i}}^{\mathrm{W}}$ and ${ }_{25} \mathrm{ASDR}^{\mathrm{W}}{ }_{\mathrm{x}}$ represent the corresponding age-standardized white male death rates. The proportionate contributions by cause of death $\left(\mathrm{p}_{\mathrm{i}}\right)$ sum to one.

We use linear regression to estimate the proportionate contribution of each cause of death to changes in the black-white mortality difference over time (Gragnolati, Elo and Goldman 1999; Preston 1976). The cause-specific black-white difference in male 
mortality is modeled as a linear function of the overall black-white difference in mortality for each cause of death group, as follows:

$$
{ }_{25} \operatorname{ASDR}_{\mathrm{x}, \mathrm{i}, \mathrm{t}}^{\mathrm{B}}-{ }_{25} \operatorname{ASDR}_{\mathrm{x}, \mathrm{i}, \mathrm{t}}^{\mathrm{W}}=\mathrm{a}_{\mathrm{i}}+\mathrm{b}_{\mathrm{i}}\left({ }_{25} \operatorname{ASDR}_{\mathrm{x}, \mathrm{t}}^{\mathrm{B}}-{ }_{25} \operatorname{ASDR}_{\mathrm{x}, \mathrm{t}}^{\mathrm{W}}\right),
$$

where ${ }_{25} \mathrm{ASDR}_{\mathrm{x}, \mathrm{i}, \mathrm{t}}^{\mathrm{B}}{ }_{25} \mathrm{ASDR}_{\mathrm{x}, \mathrm{i}, \mathrm{t}}^{\mathrm{W}}{ }_{25} \mathrm{ASDR}_{\mathrm{x}, \mathrm{t}}^{\mathrm{B}}$, and ${ }_{25} \mathrm{ASDR}_{\mathrm{x}, \mathrm{t}}^{\mathrm{W}}$ are defined as in the previous equation, except that all measures in equation (2) refer to year $t$. For each age group, the sum of the $b_{i}$ coefficients across all causes equals one. Thus, $b_{i}$ can be interpreted as the proportionate change in the black-white difference in the overall death rate that is attributable to a change in the black-white difference in the death rate for cause $i$. The regression model is estimated for three time periods: 1960-67, 1968-83, and 1984-95. To eliminate bias in our estimates due to changes in the classification of deaths to "symptoms and ill-defined conditions," we included the black-white difference for these causes as an independent variable in all regressions (Gragnolati, Elo and Goldman 1999; Preston 1976).

\section{Results}

\subsection{Trends in all-cause mortality}

Figures 1 and 2 present all-cause mortality trends by age and race. Although black death rates exceeded white rates throughout the period, the black-white differences in male mortality were not uniform. They widened during the 1960s, peaking in the late 1960s-early 1970s. The differences subsequently declined and reached their lowest point in the early 1980s, but increased thereafter. 
Demographic Research - Special Collection 2: Article 10

-- Determinants of Diverging Trends in Mortality --

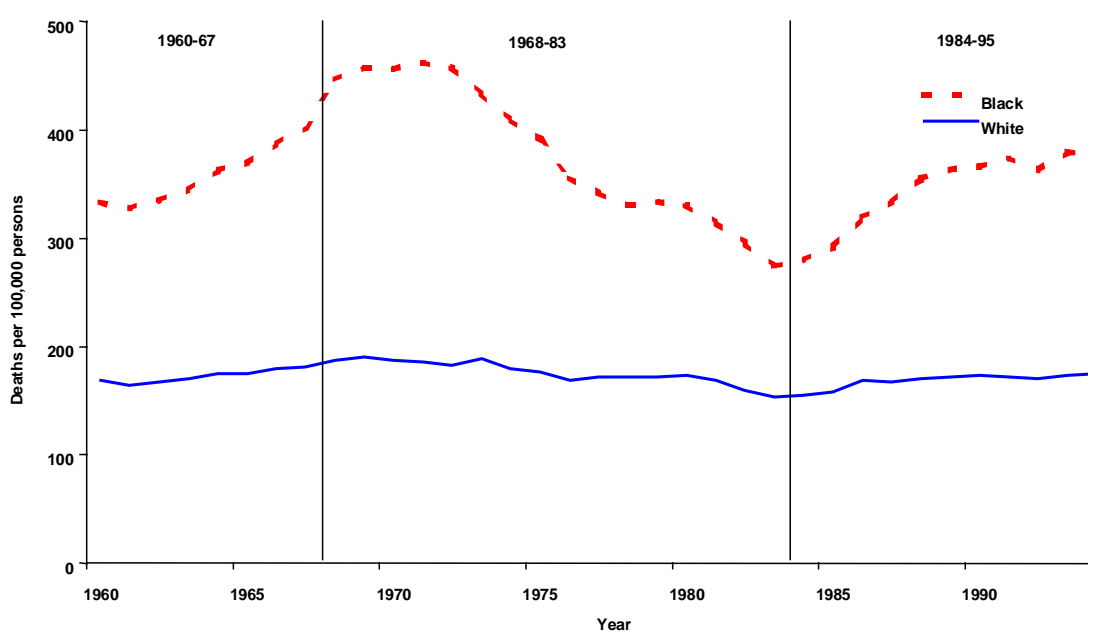

Figure 1: $\quad$ Age-Standardized Death Rates from All Causes Combined at Ages 15-39 by Time Period, Black and White Males, 1960 - 1995

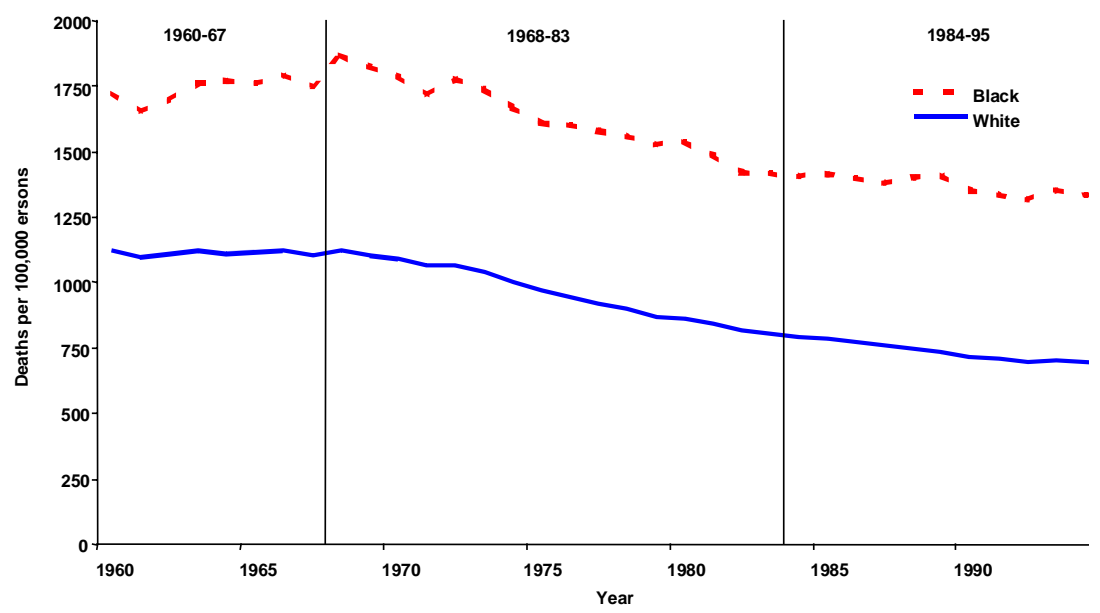

Figure 2: $\quad$ Age-Standardized Death Rates from All Causes Combined at Ages 40-64 by Time Period, Black and White Males, 1960 - 1995 
Death rates for black males at ages 15-39, in particular, exhibit considerable variation over time, and black-white differences at these ages were largely driven by more pronounced fluctuations in black than white age-standardized death rates. Black male mortality increased sharply from 1960 to the early 1970s. It fell thereafter until the early 1980s when it was below its 1960 value. This favorable trend reversed in the 1980s when black male mortality began to rise again. In contrast, age-standardized death rates for white males showed much less variation over time, although they too increased from 1960 to the early 1970s, declined between early 1970s and early 1980s, and increased thereafter. In 1993-95, male mortality at ages 15-39 was 12 percent higher for blacks and 4 percent higher for whites than it had been in 1960-62 (Table 1).

Table 1: $\quad$ Age-Standardized Death Rates per 100,000 Persons for Selected Causes of Death at Ages 15-39, Black and White Males, 1960-62 and 1993-95

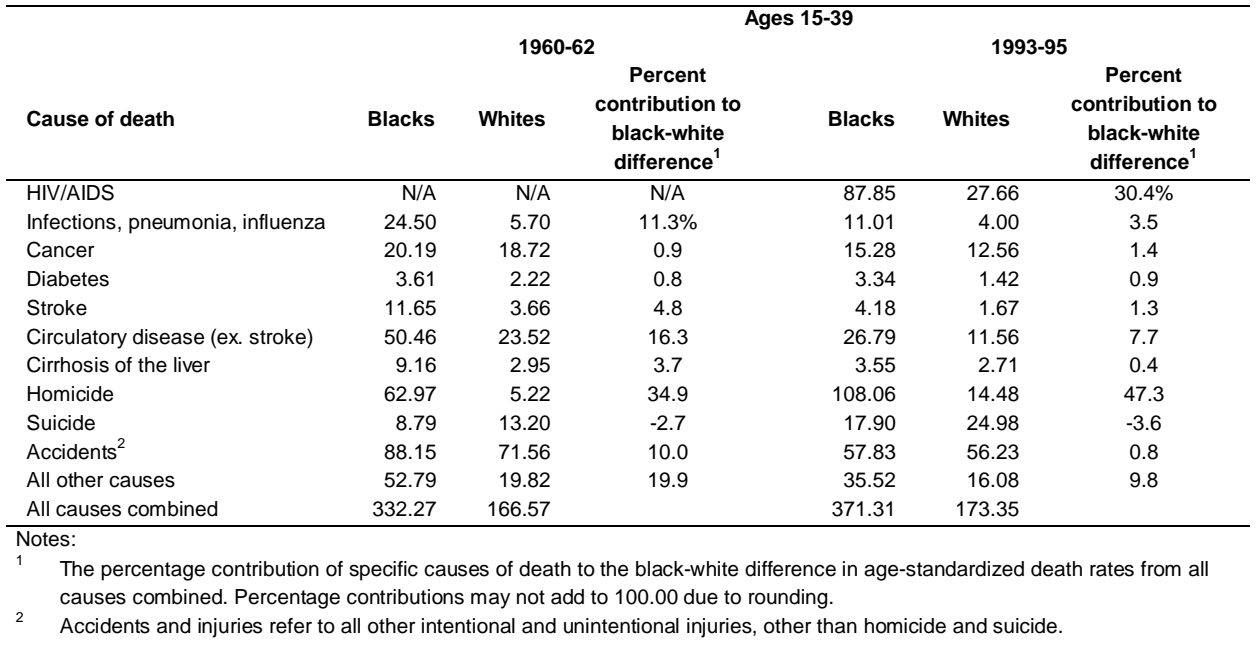

Mortality trends at ages 40-64 displayed both similarities and differences with those at younger ages. During the 1960s, white and black age-standardized death rates at ages 40-64 fluctuated within a relatively small range, although the trend was more favorable for whites than blacks, resulting in the widening of the black-white mortality difference. Subsequently, death rates for whites declined steadily until 1995. In contrast, the black death rate fell only until the mid-1980s when its fall stagnated (Figure 2). Between 1960-62 and 1993-95 male mortality at ages 40-64 declined by 37 percent for whites and by 21 percent for blacks (Table 2). 
Demographic Research - Special Collection 2: Article 10

-- Determinants of Diverging Trends in Mortality --

Table 2: $\quad$ Age-Standardized Death Rates per 100,000 Persons for Selected Causes of Death at Ages 40-64, Black and White Males, 1960-62 and 1993-95

\begin{tabular}{|c|c|c|c|c|c|c|}
\hline \multirow[b]{3}{*}{ Cause of death } & \multicolumn{6}{|c|}{ Ages 40-64 } \\
\hline & \multicolumn{3}{|c|}{$1960-62$} & \multicolumn{3}{|c|}{ 1993-95 } \\
\hline & Blacks & Whites & $\begin{array}{l}\text { Percent } \\
\text { contribution to } \\
\text { black-white } \\
\text { difference }^{1}\end{array}$ & Blacks & Whites & $\begin{array}{c}\text { Percent } \\
\text { contribution to } \\
\text { black-white } \\
\text { difference }^{1}\end{array}$ \\
\hline HIV/AIDS & $\mathrm{N} / \mathrm{A}$ & $\mathrm{N} / \mathrm{A}$ & $\mathrm{N} / \mathrm{A}$ & 135.06 & 32.82 & $15.8 \%$ \\
\hline Infections, pneumonia, influenza & 127.10 & 38.70 & $15.2 \%$ & 55.27 & 19.06 & 5.6 \\
\hline Cancer, lung & 73.27 & 65.74 & 1.3 & 121.77 & 75.09 & 7.2 \\
\hline Cancer, all other & 207.36 & 149.17 & 10.0 & 208.16 & 130.23 & 12.0 \\
\hline Diabetes & 25.61 & 14.30 & 1.9 & 40.12 & 16.53 & 3.6 \\
\hline Stroke & 190.29 & 58.03 & 22.7 & 67.28 & 20.58 & 7.2 \\
\hline Circulatory disease (ex. stroke) & 640.90 & 528.75 & 19.3 & 383.34 & 223.00 & 24.8 \\
\hline Cirrhosis of the liver & 34.26 & 34.67 & -0.1 & 38.08 & 24.81 & 2.1 \\
\hline Homicide & 48.91 & 4.91 & 7.6 & 37.06 & 6.92 & 4.7 \\
\hline Suicide & 10.85 & 31.79 & -3.6 & 11.17 & 24.16 & -2.0 \\
\hline Accidents and injuries $^{2}$ & 110.59 & 70.43 & 6.9 & 76.20 & 43.72 & 5.0 \\
\hline All other causes & 222.26 & 113.50 & 18.7 & 170.39 & 80.16 & 13.9 \\
\hline All causes combined & $1,691.40$ & $1,109.99$ & & $1,343.90$ & 697.08 & \\
\hline \multicolumn{7}{|l|}{ Notes: } \\
\hline $\begin{array}{l}\text { The percentage contribution } \\
\text { causes combined. Percentag }\end{array}$ & $\begin{array}{l}\text { specific ca } \\
\text { contributio }\end{array}$ & $\begin{array}{l}\text { ses of death } \\
\text { s may not a }\end{array}$ & $\begin{array}{l}\text { o the black-white } \\
\text { to } 100.00 \text { due to }\end{array}$ & e in age-st & ardized dea & rates from all \\
\hline Accidents and injuries refer $t$ & all other int & ntional and & intentional injuries & han homici & and suicide. & \\
\hline
\end{tabular}

\subsection{Cause-specific contributions to black-white differences in male mortality}

Age-standardized death rates of black men exceeded those of white men for most cause of death groups examined, and the contribution of various causes of death to the blackwhite disparity in all-cause mortality varied by age and over time. Tables 1 and 2 present age-standardized death rates by age, race, and cause for 1960-62 and 1993-95. Figures 3 and 5 summarize cause-specific contributions to the black-white difference in overall mortality for these two time points. Table 3 displays the percentage contributions of various cause of death groups to the change in the black-white difference in all-cause mortality over time, and Figures 4 and 6 graph the information presented in Table 3.

Ages 15-39

Intentional and unintentional injuries, which are leading causes of death at ages 15-39, made the largest contributions to the black-white inequality in male mortality in adolescence and young adulthood. Among these causes, deaths from homicide were the most important, accounting for 35 percent of the overall black-white difference in 196062 and 47 percent in 1993-95 (Table 1 and Figure 3). 
Demographic Research - Special Collection 2: Article 10

-- Determinants of Diverging Trends in Mortality --

Table 3: $\quad$ Percentage Contribution of Each Cause of Death Group to Change in the Black-White Difference in Age-Standardized Male Death Rates at Ages 15-39 and 40-64 by Time Period, 1960-95

\begin{tabular}{|c|c|c|c|c|c|c|}
\hline \multirow[b]{3}{*}{ Cause of death } & \multicolumn{6}{|c|}{ Ages 15-39 } \\
\hline & \multicolumn{2}{|c|}{$1960-67$} & \multicolumn{2}{|c|}{$1968-83$} & \multicolumn{2}{|c|}{$1984-95$} \\
\hline & $\begin{array}{c}\text { Increase in } \\
\text { black- } \\
\text { white } \\
\text { difference }\end{array}$ & $\begin{array}{l}\text { Decrease } \\
\text { in black- } \\
\text { white } \\
\text { difference }\end{array}$ & $\begin{array}{l}\text { Increase in } \\
\text { black- } \\
\text { white } \\
\text { difference }\end{array}$ & $\begin{array}{l}\text { Decrease } \\
\text { in black- } \\
\text { white } \\
\text { difference }\end{array}$ & $\begin{array}{l}\text { Increase in } \\
\text { black- } \\
\text { white } \\
\text { difference }\end{array}$ & $\begin{array}{c}\text { Decrease } \\
\text { in black- } \\
\text { white } \\
\text { difference }\end{array}$ \\
\hline HIV/AIDS & $\mathrm{N} / \mathrm{A}$ & $\mathrm{N} / \mathrm{A}$ & $\mathrm{N} / \mathrm{A}$ & $\mathrm{N} / \mathrm{A}$ & 60.98 & \\
\hline Infections, pneumonia, influenza & & 8.09 & & 8.79 & & 2.91 \\
\hline Cancer & & 1.96 & 0.23 & & 0.18 & \\
\hline Diabetes & 1.00 & & & 0.57 & 0.71 & \\
\hline Stroke & 2.65 & & & 3.67 & & 1.64 \\
\hline Circulatory disease (ex. stroke) & 11.65 & & & 10.67 & & 3.51 \\
\hline Cirrhosis of the liver & 15.28 & & & 3.96 & & 7.01 \\
\hline Homicide & 59.10 & & & 23.22 & 53.91 & \\
\hline Suicide & & 0.17 & & 2.27 & 2.50 & \\
\hline Accidents and injuries ${ }^{1}$ & 12.50 & & & 34.58 & 5.90 & \\
\hline \multirow[t]{2}{*}{ All other causes } & 8.04 & & & 12.50 & & 9.11 \\
\hline & 1960 & 1967 & 1968 & 1983 & 1984 & 1995 \\
\hline \multicolumn{7}{|l|}{ Black-White Difference in Male } \\
\hline \multirow[t]{3}{*}{$\begin{array}{l}\text { Age-Standardized Death Rates per } \\
100,000 \text { Population }\end{array}$} & 164.22 & 221.58 & 259.43 & 120.37 & 124.96 & 186.02 \\
\hline & \multicolumn{6}{|c|}{ Ages $40-64$} \\
\hline & \multicolumn{2}{|c|}{$1960-67$} & \multicolumn{2}{|c|}{ 1968-83 } & \multicolumn{2}{|c|}{$1984-95$} \\
\hline Cause of death & $\begin{array}{l}\text { Increase in } \\
\text { black- } \\
\text { white } \\
\text { difference }\end{array}$ & $\begin{array}{l}\text { Decrease } \\
\text { in black- } \\
\text { white } \\
\text { difference }\end{array}$ & $\begin{array}{l}\text { Increase in } \\
\text { black- } \\
\text { white } \\
\text { difference }\end{array}$ & $\begin{array}{l}\text { Decrease } \\
\text { in black- } \\
\text { white } \\
\text { difference }\end{array}$ & $\begin{array}{l}\text { Increase in } \\
\text { black- } \\
\text { white } \\
\text { difference }\end{array}$ & $\begin{array}{l}\text { Decrease } \\
\text { in black- } \\
\text { white } \\
\text { difference }\end{array}$ \\
\hline HIV/AIDS & $\mathrm{N} / \mathrm{A}$ & $\mathrm{N} / \mathrm{A}$ & $\mathrm{N} / \mathrm{A}$ & $\mathrm{N} / \mathrm{A}$ & 24.57 & \\
\hline Infections, pneumonia, influenza & 36.51 & & & 15.66 & 5.99 & \\
\hline Cancer, lung & 24.75 & & 1.82 & & & 6.29 \\
\hline Cancer, all other & & 5.28 & 8.24 & & 0.66 & \\
\hline Diabetes & 0.93 & & & 1.14 & 5.11 & \\
\hline Stroke & & 8.22 & & 21.78 & 0.36 & \\
\hline Circulatory disease (ex. stroke) & 11.88 & & & 44.14 & 43.75 & \\
\hline Cirrhosis of the liver & 6.41 & & & 0.73 & & 0.45 \\
\hline Homicide & 12.43 & & 0.76 & & & 5.91 \\
\hline Suicide & 0.04 & & & 2.12 & 0.95 & \\
\hline Accidents and injuries ${ }^{1}$ & 17.56 & & & 10.12 & 14.61 & \\
\hline \multirow[t]{2}{*}{ All other causes } & 2.91 & & & 15.12 & 16.65 & \\
\hline & 1960 & 1967 & 1968 & 1983 & 1984 & 1995 \\
\hline Black-White Difference in Male & & & & & & \\
\hline $\begin{array}{l}\text { Age-Standardized Death Rates per } \\
100,000 \text { Population }\end{array}$ & 597.97 & 642.91 & 743.87 & 614.85 & 614.87 & 649.20 \\
\hline
\end{tabular}


As seen in Table 3 and Figure 4, trends in homicide mortality were also a key determinant of changes in the black-white difference in all-cause mortality over time. Homicide made the largest contribution to the increase in the black-white gap in the 1960s, a substantial contribution to its narrowing between 1968 and 1983, and it, together with HIV/AIDS, was largely responsible for the widening of the black-white mortality difference between 1984 and 1995. In 1993-95, the age-standardized death rate from homicide was higher for both blacks and whites than it had been in 1960-62, with the absolute increase being almost five times greater for blacks than whites (Table $1)$.

Deaths from intentional and unintentional injuries, other than homicide and suicide, made smaller contributions to the black-white difference in 1960-62 and 199395. These causes also played a less important role in explaining fluctuations in the black-white inequality over time, except in the period 1968-83 when they made the largest contribution to the narrowing of the black-white difference. By 1993-95, these causes explained only 0.8 percent of the black-white difference in all-cause mortality. In contrast to all other cause of death groups examined, suicide is the only cause from which death rates were higher for whites than for blacks at ages 15-39 both in 1960-62 and 1993-95. However, deaths from suicide made relatively small contributions to the overall black-white difference in all-cause mortality and to changes in this difference over time (Tables 1 and 3; Figures 3 and 4).

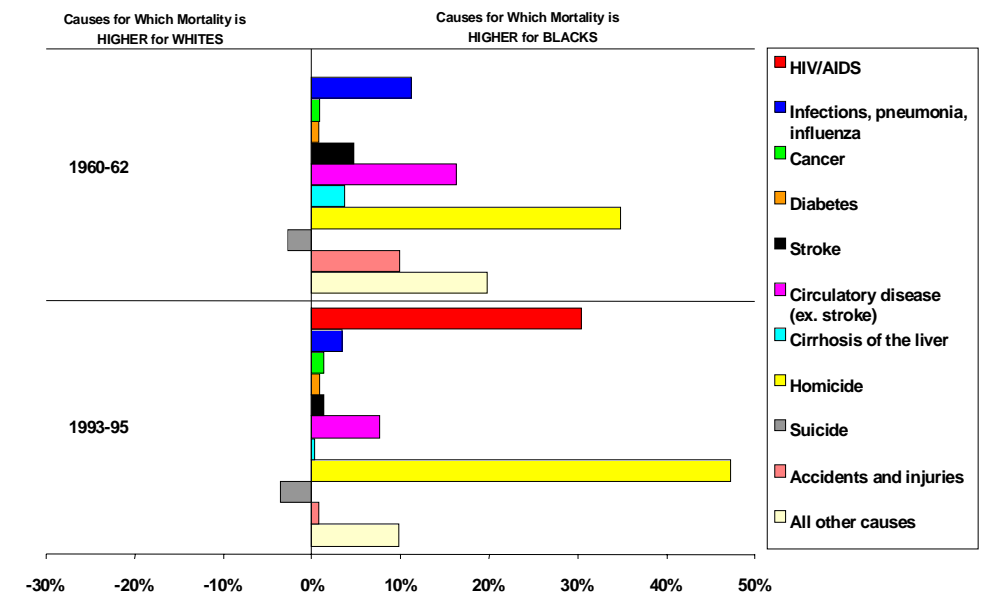

Note: Cause-specific contributions are shown in the order indicated by the legend. Estimates for HIV/AIDS are only for the period 1993-1995.

Figure 3: $\quad$ Percent Contribution of Selected Causes to Black-White Difference in Male Mortality, Ages 15-39, 1960-62 and 1993-95 
During the 1980s and early 1990s, death rates from HIV/AIDS rose rapidly and this increase was more pronounced for black men than for white men. By 1993-95, the age-standardized black male death rate from HIV/AIDS at ages 15-39 was three times as high as the rate for white males, and HIV/AIDS alone accounted for 30 percent of the black-white difference in all-cause mortality at these ages (Table 1 and Figure 3). HIV/AIDS also made the largest contribution to the widening of the black-white difference in all-cause mortality among young men between 1984 and 1995 (Table 3 and Figure 4).

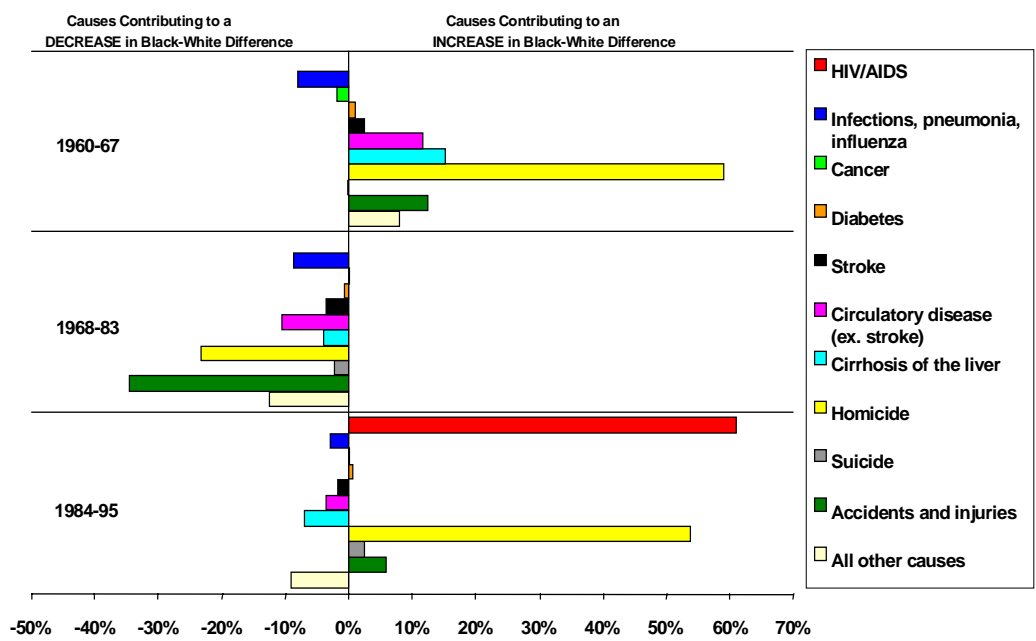

Note: Cause-specific contributions are shown in the order indicated by the legend. Estimates for HIV/AIDS are only for the period 1984-1995.

Figure 4: Cause-specific Contributions to Change in Black-White Difference in Male Mortality, Ages 15-39, 1960-95

Mortality trends from infections, pneumonia, and influenza, on the other hand, favored the narrowing of the black-white mortality difference between 1960 and 1995. In 196062, these causes accounted for 11 percent of the black-white difference in male mortality in adolescence and young adulthood, but by 1993-95 their contribution had declined to 4 percent. Overall mortality trends from such chronic diseases as cancer, diabetes, stroke, and other circulatory diseases also led to the narrowing of the blackwhite difference in male mortality between 1960 and 1995, despite their contribution to an increase in this difference in the 1960s. These causes explained 23 percent of the black-white difference in all-cause mortality at ages 15-39 in 1960-62 but only 11 
percent in 1993-95. Nevertheless, despite this decline black male death rates from these causes were more than twice as high as white male rates in 1993-95, except from cancer. A similar pattern is found for cirrhosis of the liver, whose contribution to the black-white difference in all-cause mortality declined from 3.7 percent in 1960-62 to 0.4 percent in 1993-95 (Table 1).

\section{Ages 40-64}

Not surprisingly, at ages 40-64 chronic diseases made a much larger contribution to the black-white difference in male mortality than was the case at younger ages. Cancer, diabetes, stroke, and other circulatory diseases accounted for 55 percent of the blackwhite difference in all-cause mortality at ages 40-64 both in 1960-62 and 1993-95. The relative importance of these causes, however, changed over time. The decline in the black-white difference in stroke mortality is particularly notable. Stroke accounted for 23 percent of the overall difference in 1960-62 but only 7 percent in 1993-95. In contrast, the contribution of death rates from other cardiovascular diseases to the blackwhite difference increased from 19 percent in 1960-62 to 25 percent in 1993-95 even though death rates from these causes declined for both black and white men. The increased contribution of these causes to the black-white difference in all-cause mortality reflects a more rapid mortality decline for whites than for blacks, particularly after 1983. Only in the period 1968-83 did mortality from these causes decline more rapidly for blacks than for whites, a trend that led to the narrowing of the black-white difference in all-cause mortality during this period (Table 3 and Figure 6). 
Demographic Research - Special Collection 2: Article 10

-- Determinants of Diverging Trends in Mortality --

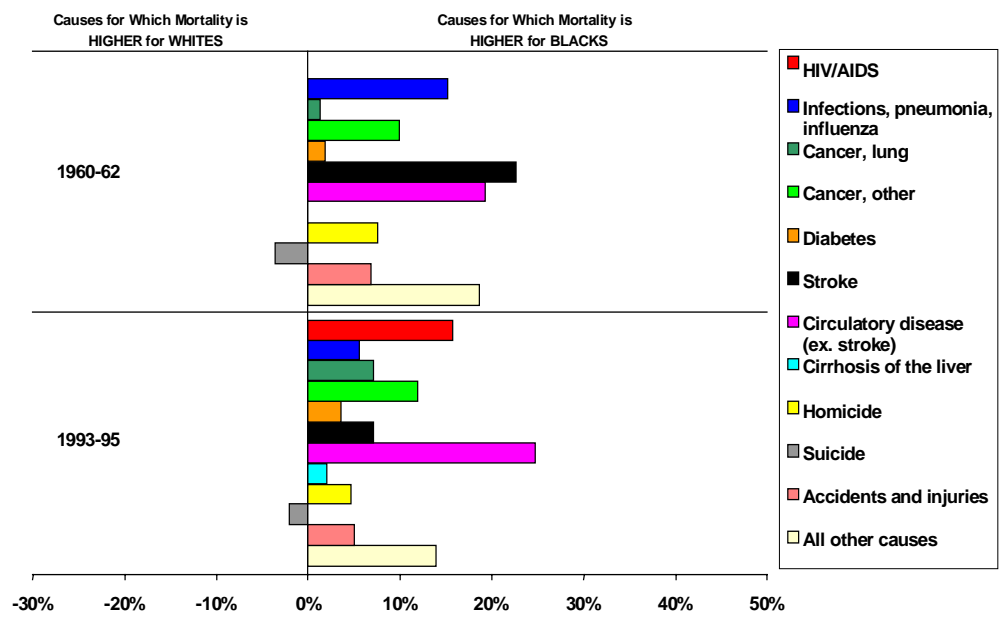

Note: Cause-specific contributions are shown in the order indicated by the legend. Estimates for HIV/AIDS are only for the period 1993-1995.

Figure 5: $\quad$ Percent Contribution of Selected Causes to Black-White Difference in Male Mortality, Ages 40-64, 1960-62 and 1993-95

Cancer mortality trends were also more adverse for black men than for white men. In particular, increasing death rates from lung cancer between 1960 and the early 1980s were more rapid for blacks than for whites and led to a widening of the black-white difference in all-cause mortality between 1960 and 1983. Thereafter, the trend reversed as lung cancer mortality began to decline more rapidly for blacks than for whites, although the age-standardized black male death rate from lung cancer remained 60 percent above the white male rate in 1993-95. The black-white difference in mortality from all other cancers combined exhibited much less variation over time and made relatively small contributions to the change in the black-white difference in all-cause mortality. Mortality from cancers, other than lung cancer, accounted for 10 percent of the black-white inequality in all-cause mortality in 1960-62 and 12 percent in 1993-95 (Table 2). Similarly, mortality from diabetes and cirrhosis of the liver explained only a small fraction of the black-white difference in all-cause mortality or changes in this difference over time (Tables 2 and 3; Figures 5 and 6). 


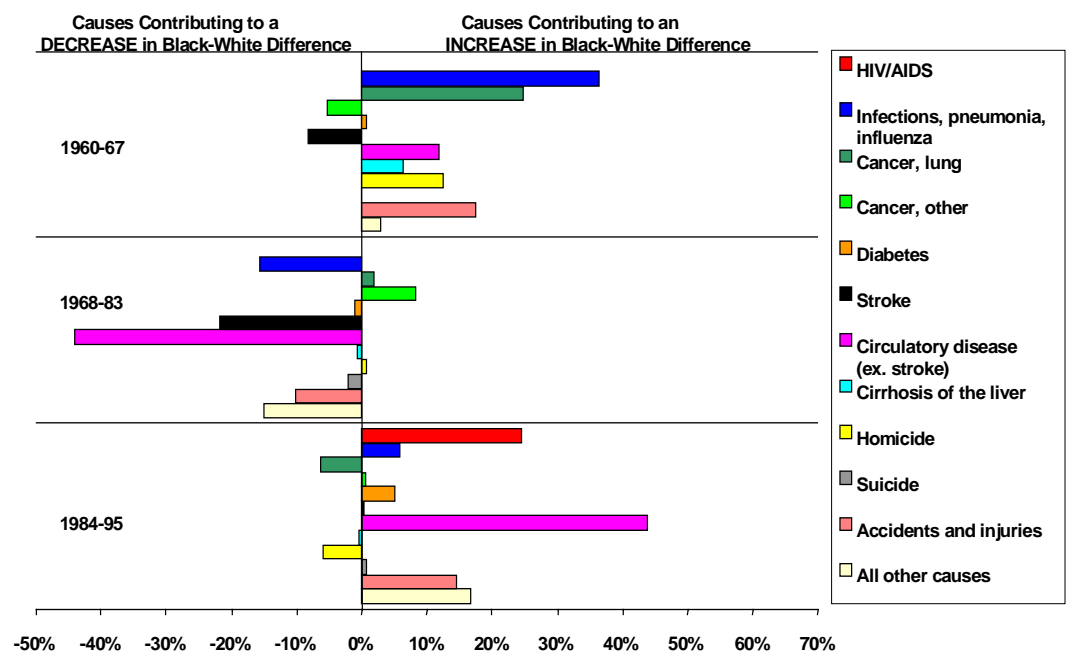

Note: Cause-specific contributions are shown in the order indicated by the legend. Estimates for HIV/AIDS are only for the period 1984-1995.

Figure 6: Cause-specific Contributions to Change in Black-White Difference in Male Mortality, Ages 40-64, 1960-95

As expected, intentional and unintentional injuries were less important at older ages than at younger ages. Homicide and other intentional and unintentional injuries accounted for 14 percent of the black-white difference in all-cause mortality in 1960-62 and 10 percent in 1993-95. As was the case at younger ages, death rates from suicide were also higher for whites than for blacks at ages 40-64 both in 1960-62 and 1993-95, although the black-white difference was smaller in the 1990s than it had been in the 1960s (Table 2).

Finally, the impact of HIV/AIDS is also evident at older ages. The steep rise in HIV/AIDS mortality in the 1980s was more pronounced for black men than for white men at ages 40-64, just as it had been at younger ages. As a result, HIV/AIDS mortality made a substantial contribution to the increase in the black-white difference in all-cause mortality. It accounted for 25 percent of the increase in the mortality disparity between 1984 and 1995, and in 1993-95 HIV/AIDS explained 16 percent of the blackwhite inequality in all-cause mortality among men at ages 40-64 (Tables 2 and 3; Figures 5 and 6). 


\section{Discussion}

Our findings reveal persistently higher death rates for black men than for white men for all cause of death groups examined, except for suicide. These inequalities are rooted in black-white differences in daily living experiences and economic and social conditions, including disparities in socioeconomic status (SES), residential environments, access to health care, quality of that care, as well as other consequences of racism that have led to differential access to societal resources for whites and African Americans (Williams and Collins 1995; Williams 2001). Our findings also reveal considerable variation in black-white disparities by cause of death and by age, as well as changes in the relative importance of various causes to the black-white male mortality difference over time. These results suggest that the consequences of black-white differences in SES, living conditions, access to health care, and residential segregation vary by cause of death. In previous studies, black-white differences in SES have explained more of the blackwhite difference in mortality from accidents, violence, and lung cancer than other forms of cancer, cardiovascular diseases, or infectious diseases (Kallan 1997; Richardus and Kunst 2001; Rogers, Hummer and Nam 2000).

The increase in black-white differences in male mortality between 1984 and 1995 represents an unfortunate reversal of the decline in these disparities that occurred between 1968 and 1983. The more adverse mortality trends for black men than for white men resulted not only in an increase in the black-white mortality disparity, but they also led to a decline in black male life expectancy in the mid-1980s (Kochanek, Maurer and Rosenberg 1994). Such a decline is highly unusual in a developed country at the end of the $20^{\text {th }}$ century.

Mortality trends from HIV/AIDS and homicide were largely responsible for the increase in all-cause black male mortality at ages 15-39 and for the rise in the blackwhite disparity between 1984 and 1995. These causes explained 78 percent of the black-white difference in male mortality at ages 15-39 by 1993-95. Residential segregation and concentrated urban poverty place black Americans at a greater risk of death from both causes (Geronimus et al. 1996; Massey 1995; Peterson and Krivo 1993). In addition, African Americans are less likely than whites to receive the most advanced treatment for HIV/AIDS, thus lowering their chances of survival (Smedley, Stith and Nelson 2002). Although age-standardized death rates from HIV/AIDS began to level off in the mid-1990s, with the first declines in death rates documented for 1996, these declines have been less pronounced for blacks than for whites (Felming et al. 2000). The key to reducing the disproportionate burden of HIV/AIDS-related mortality experienced by black men will require improved access to effective treatment, widespread testing, and more effective prevention strategies (Levi and Kates 2000). 
Although chronic diseases also contribute to the black-white mortality difference at younger ages, their contribution is more pronounced at ages 40-64. In this context, several of our findings are of interest. Trends in death rates from stroke have made a substantial contribution to the narrowing of the black-white mortality difference between 1960 and 1995, despite the fact that black death rates $(67.3$ per 100,000) were still three times as high as white rates (20.6 per 100,000) in 1993-95. Widespread screening and pharmacologic treatment for hypertension may have contributed to the rapid decline in stroke mortality among black men (Cooper et al. 1981).

In contrast, mortality trends from circulatory diseases (other than stroke) have been less favorable. Circulatory diseases were leading causes of death at ages 40-64 in 196062 and 1993-95 for both black and white men, with black death rates exceeding white rates throughout the 1960-95 period. Lower death rates from coronary heart disease for blacks than whites documented elsewhere are not evident at ages 40-64 at any time between 1960 and 1995 (Liao and Cooper 1995). Although circulatory disease mortality declined more rapidly among blacks than whites from the late 1960s to the mid to late-1970s, the overall trend between 1960 and 1995 has been less encouraging for African Americans than whites. Between 1960-62 and 1993-95, the agestandardized death rate from circulatory diseases declined by 58 percent for white men but by only 40 percent for black men. Trends in circulatory disease mortality will play an important role in determining the magnitude of racial mortality disparities at older ages in the future. Causes of excess circulatory disease mortality among black men are multifaceted and have been attributed to racial differences in socioeconomic status, living conditions, and differential treatment of heart disease (Ford and Cooper 1995; Hayward et al. 2000; Oddone, Peterson and Weinberger 2001; Rogers 1992' Schulman et al. 1999).

Until the 1980s, trends in lung cancer mortality contributed to the widening of the black-white difference in male mortality, though the most recent period showed a reversal of this pattern. The more favorable trends in lung cancer mortality for whites are also evident in Table 2. Between 1960-62 and 1993-95, lung cancer death rates increased by 68 percent for black men at ages $40-64$ but by only 14 percent for white men. Death rates from all other cancers combined were nearly the same in 1960-62 and 1993-95 for blacks but declined slightly for whites (13 percent for whites). Higher cancer mortality among blacks than whites has been linked to both higher incidence and lower survival rates (NCHS 1994; Ragland, Selvin and Merrill 1991).

The progress made in reducing black-white differences in male mortality between 1968 and 1983 is notable. During this period, mortality trends for most causes were more favorable for black men than for white men. The 1980s thus represented an abrupt halt to the progress made in the 1970s. This turnaround coincided with the economic downturn in the early 1980s, an increase in concentrated poverty among 
blacks in metropolitan areas, a rise in the use and sale of crack cocaine, increasing inequality, and widening of socioeconomic differentials in mortality among men (Danziger and Gottschalk 1995; Massing 1998; McLoyd and Lozoff 2001; Pappas et al. 1993). Further reductions in black-white differences in male mortality will require effective public policies that address not only equal access to quality health care but also more fundamental causes of poor health (Geronimus 2000; Jackson et al. 2000; Lantz et al. 1998).

\section{Acknowledgements}

An earlier version of this paper was presented at the Annual Meeting of the Population Association of America, Washington, DC, March 2001. This research was supported by grants AG10168 and K1AG00717A from the National Institute of Aging. We would like to thank Samuel H. Preston, Beth Soldo and two anonymous reviewers for comments on an earlier version of this paper. Please send all correspondence to: Irma T. Elo, Population Studies Center, 3718 Locust Walk, Philadelphia, PA 19104. Email: popelo@pop.upenn.edu. 


\section{References}

Anderson RN, Rosenberg HM (1998). "Age Standardization of Death Rates: Implementation of the Year 2000 Standard." National Vital Statistics Reports 47:3. Hyattsville, MD: National Center for Health Statistics.

Centers for Disease Control (2001). CDC Wonder website. 〈http://wonder.cdc.gov〉.

Cooper R, Steinhauer M, Schatzkin A, Miller W (1981). "Improved Mortality among US Blacks, 1968-1978: The Role of Antiracist Struggle." Int J Health Serv, 11:511-22.

Danziger S, Gottschalk P (1995). Unequal America. New York: Russell Sage Foundation.

Elo IT, Preston SH (1996). "Educational Differentials in Mortality: United States 19791985." Soc Sci Med, 42:47-57.

Felming PL, Wortley PM, Karon JM, DeCock KM, Janssen RS (2000). "Tracking the HIV Epidemic: Current Issues, Future Challenges." Am J Public Health 90:1037-41.

Ford E, Cooper R (1995). "Racial and Ethnic Differences in Health Care Utilization of Cardiovascular Procedures: A Review of the Evidence." Health Serv Res, 30:237-51.

Geronimus AT (2000). "To Mitigate, Resist, or Undo: Addressing Structural Influences on the Health of Urban Populations." Am J Public Health, 90:867-72.

Geronimus AT, Bound J, Waidmann TA, Hillemeier MM, Burns PB (1996). "Excess Mortality among Blacks and Whites in the United States." N Engl Journal Med $335: 1552-8$.

Gragnolati M, Elo IT, Goldman N (1999). "New Insights into the Far Eastern Pattern of Mortality." Population Studies 53:81-95.

Hayward MD, Crimmins EM, Miles TP, Yang Y (2000). "The Significance of Socioeconomic Status in Explaining the Racial Gap in Chronic Health Conditions." Am Soc Review, 65:910-30.

Israel RA, Rosenberg HM, Curtin LR (1986). "Analytical Potential for Multiple Causeof-Death Data." Am J Epidemiol, 124:161-79. 
Jackson SA, Anderson RT, Johnson NJ, Sorlie PD (2000). "The Relation of Residential Segregation to All-Cause Mortality: A Study in Black and White." Am J Public Health, 90:615-7.

Kallan J (1997). "Effects of Sociodemographic Variables on Adult Mortality in the United States: Comparisons by Sex, Age, and Cause of Death." Social Biology, 44:136-147.

Kochanek KD, Maurer JD, Rosenberg HM (1994). "Why Did Black Life Expectancy Decline from 1984 through 1989 in the United States?" Am J Public Health, 84:938-44.

Lantz PM, House JS, Lepkowski JM, Williams DR, Mero RP, Chen J (1998). "Socioeconomic Factors, Health Behaviors, and Mortality: Results from a Nationally Representative Prospective Study of US Adults." JAMA, 279:1703-8.

Levi J, Kates J (2000). "HIV: Challenging the Health Care System." Am J Public Health, 90:1033-6.

Liao Y, Cooper RS (1995). "Continued Adverse Trends in Coronary Heart Disease Mortality among Blacks, 1980-91." Public Health Rep, 110:572-9.

Manton KG, Patrick CH, Johnson K (1987). "Health Differentials between Blacks and Whites: Recent Trends in Mortality and Morbidity." Milbank Quarterly, 65 (Supplement 1):129-99.

Massey DS (1995). "Getting Away with Murder: Segregation and Violent Crime in Urban America." University of Pennsylvania Law Review, 143:1203-32.

Massing M (1998). The Fix. New York: Simon and Schuster.

McLoyd VC, Lozoff B (2001). "Racial and Ethnic Trends in Children's and Adolescents' Behavior and Development." Pp. 311-350 in NJ Smelser, WJ Wilson, and F Mitchell, eds. America Becoming: Racial Trends and their Consequences. Volume II. Washington, DC: National Academy Press.

National Center for Health Statistics (1998). Health United States, 1998. Hyattsville: National Center for Health Statistics. (DHHS publication no. PHS 98-1232).

National Center for Health Statistics (1994). Health, United States, 1993. Washington, DC: US Government Printing Office. (DHHS publication no. PHS 94-1232).

National Center for Health Statistics (1989). "Advance Report of Final Mortality Statistics, 1984." Monthly Vital Statistics Report 38(5): Supplement 2. Hyattsville, MD: Public Health Service. 
National Center for Health Statistics. 1986. "Advance Report of Final Mortality Statistics, 1983." Monthly Vital Statistics Report, 34(6):Supplement 2. Hyattsville, MD: Public Health Service.

Oddone EZ, Peterson LA, Weinberger M (2001). "Health Care Use in the Veterans Health Administration: Racial Trends and the Spirit of Inquiry." In Smelser NJ, Wilson WJ, Mitchell F, eds. America Becoming: Racial Trends and their Consequence. Volume II:411-29. Washington, DC: National Academy Press.

Pappas G, Queen S, Hadden W, Fisher G (1993). "The Increasing Disparity in Mortality between Socioeconomic Groups in the United States, 1960 and 1986." N Engl J Med, 329:103-9.

Peterson RD, Krivo LJ (1993). "Racial Segregation and Black Urban Homicide." Social Forces, 71:1001-26.

Potter LB (1991). "Socioeconomic Determinants of White and Black Male's Life Expectancy Differentials, 1980." Demography 28:303-21.

Preston SH (1976). Mortality Patterns in National Populations. New York: Academic Press.

Preston SH, Elo IT, Foster A, Fu H (1998). "Reconstructing the Size of the African American Population by Age and Sex, 1930-1990." Demography, 35:1-21.

Ragland KE, Selvin S, Merrill DW (1991). "Black-White Differences in Stage-specific Cancer Survival: Analysis of Seven Selected Sites." Am J Epidemiol, 133:67282.

Richardus JH, Kunst AE (2001). "Black-white Differences in Infectious Disease Mortality in the United States." Am J Public Health, 91:1251-1253.

Robinson JG, Ahmed B, Gupta PD, Woodrow KA (1993). "Estimation of Population Coverage in the 1990 United States Census based on Demographic Analysis." J Am Stat Assoc, 88:1061-71.

Rogers RG (1992). "Living and Dying in the U.S.A.: Sociodemographic Determinants of Death among Blacks and Whites." Demography, 29:287-303.

Rogers RG, Hummer RA, Nam CB (2000). Living and Dying in the U.S.A: Behavioral, Health, and Social Differentials of Adult Mortality. New York: Academic Press.

Rosenberg, HM (1999). "Cause of Death as a Contemporary Problem." Journal of the History of Medicine, 54:133-53. 
Schulman, KA, Berlin JA, Harless W, et al. (1999). "The Effect of Race and Sex on Physicians' Recommendations for Cardiac Catheterization." $N$ Engl J Med, 340:618-26.

Smedley BD, Stith AY, Nelson AR, eds (2002). Unequal Treatment: Confronting Racial and Ethnic Disparities in Health Care. Washington, DC: National Academy Press.

Smelser NJ, Wilson WJ, Mitchell F, eds (2001). America Becoming: Racial Trends and their Consequences. Volume II. Washington, DC: National Academy Press.

U.S. Census Bureau (1988). The Coverage of Population in the 1980 Census. Washington, DC: US Government Printing Office. (Census publication no. PHC80-E4).

U.S. Census Bureau (1974). Estimates of the Population of the United States, by Age, Sex, and Race: April 1, 1960 to July 1, 1973. Washington, DC: US Government Printing Office, (Census publication no. P25-519).

Williams DR (2001). "Racial Variations in Adult Health Status: Patterns, Paradoxes, and Prospects. Pp. 371-410 in NJ Smelser, WJ Wilson, and F Mitchell, eds. America Becoming: Racial Trends and their Consequences. Volume II. Washington, DC: National Academy Press.

Williams DR, Collins C (1995). "U.S. Socioeconomic and Racial Differentials in Health: Patterns and Explanations." Annual Review of Sociology, 21:349-386. 
Demographic Research - Special Collection 2: Article 10

-- Determinants of Diverging Trends in Mortality --

\section{Appendix}

Table A1: International Classification of Disease (ICD) Numbers for Each Cause Group, According to ICD Revision

\begin{tabular}{|c|c|c|c|}
\hline Title & $\begin{array}{c}\text { Seventh Revision } \\
(1960-67)\end{array}$ & $\begin{array}{c}\text { Eighth Revision } \\
(1968-78)\end{array}$ & $\begin{array}{c}\text { Ninth Revision } \\
(1979-95)\end{array}$ \\
\hline HIV/AIDS & $\mathrm{N} / \mathrm{A}$ & $N / A$ & $\begin{array}{l}279.1(1984-86), 042-044 \\
(1987-95)\end{array}$ \\
\hline Infections, pneumonia, influenza & $001-138,480-493$ & $000-136,470-486$ & $001-139,480-487$ \\
\hline Cancer, lung & 162 & 162 & 162 \\
\hline Cancer, all other & $140-161,163-239$ & $140-161,163-239$ & $140-161,163-239$ \\
\hline Diabetes & 260 & 250 & 250 \\
\hline Stroke & $330-334$ & $430-438$ & $430-438$ \\
\hline Circulatory diseases (ex. stroke) & $400-468$ & $390-429,440-458$ & $390-429,440-459$ \\
\hline Cirrhosis of the liver & 581 & 571 & 571 \\
\hline Homicide & E980-E985 & E960-E978 & E960-E978 \\
\hline Suicide & E970-E979 & E950-E959 & E950-959 \\
\hline Accidents and injuries ${ }^{1}$ & E800-E965, E990-E999 & E800-E949, E980-E999 & E800-E949, E980-E999 \\
\hline All other causes & $\begin{array}{l}240-254,270-326,340-398 \\
470-475,500-580,582-795\end{array}$ & $\begin{array}{l}240-246,251-389,460-466 \\
490-570,572-796\end{array}$ & $\begin{array}{l}240-246,251-389,460-478 \\
490-570,572-799\end{array}$ \\
\hline
\end{tabular}

Note:

1 Accidents and injuries refer to all other intentional and unintentional injuries, other than homicide and suicide. 